\title{
CURRENT ISSUES OF MECHANICS
}

\section{DOI https://doi.org/10.30525/978-9934-26-043-8-15}

\section{МОДЕЛЬ «ТРИЗУБЕЦЬ» ЗОНИ ПЕРЕДРУЙНУВАННЯ В КІНЦІ ТРІЩИНИ НОРМАЛЬНОГО ВІДРИВУ У КУТОВІЙ ТОЧЦІ ЛАМАНОЇ МЕЖІ РОЗДІЛУ ДВОХ МАТЕРІАЛІВ}

\author{
Дудик М. В. \\ кандидат фізико-математичних наук, доцент, \\ професор кафедри фізики та інтегративних технологій навчання \\ Уманський державний педагогічний університет імені Павла Тичини \\ Решітник Ю. В. \\ кандидат фізико-математичних наук, \\ доиент кафедри фізики та інтегративних технологій навчання \\ Уманський державний педагогічний університет імені Павла Тичини \\ м. Умань, Черкаська область, Украӥна
}

Кутова точка ламаної межі розділу двох різних матеріалів, з якої виходить тріщина нормального відриву, $є$ концентратором напружень зі степеневою особливістю, що призводить до утворення в іїі околі зони передруйнування. Зона передруйнування в пружно-пластичному матеріалі має складну структуру і містить досить розвинуту пластичну область, в якій переважають зсувні деформації, та прилеглу до вершини концентратора значно меншу за розмірами область деструкції матеріалу з підвищеним рівнем як зсувних, так і відривних деформацій.

В даній роботі в умовах плоскої деформації здійснено дослідження маломасштабної зони передруйнування в кінці тріщини нормального відриву, що виходить 3 кутової точки межі поділу двох різних середовищ. 3 урахуванням симетрії задачі для іiі опису використовується модель «тризубець» [1], згідно 3 якою розвиток зони відбувається у два етапи (рис. 1).

На першому етапі з вершини тріщини під деяким кутом до іiі початкового напрямку в одному з матеріалів з'єднання симетрично поширюються дві вузькі бічні пластичні смуги, що моделюються відрізками лінії розриву дотичного переміщення. Оскільки їх поява не усуває концентрацію напружень в околі вершини, то на наступному 
етапі передбачається утворення на продовженні тріщини вторинної зони - зони деструкції значно меншої довжини, що в силу симетрії моделюється відрізком лінії розриву нормального переміщення.

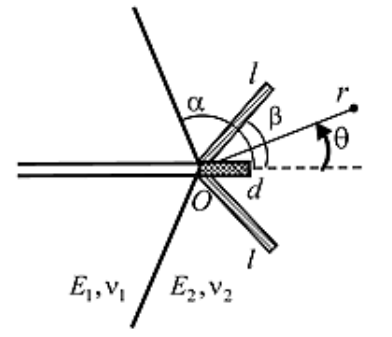

Pис. 1

Розрахунок параметрів зони передруйнування виконано за допомогою методу Вінера - Гопфа у поєднанні 3 апаратом інтегрального перетворення Мелліна та деякими положеннями теорії функцій комплексної змінної, подібно до розв'язання аналогічних задач в $[2,3]$. Зовнішне навантаження задавалось через коефіцієнт інтенсивності напружень у розв'язку зовнішньої задачі, яка відповідає відсутності зони передруйнування. Для формулювання умови на нескінченості використовувався метод зрощування асимптотичних розвинень розв'язків внутрішньої і зовнішньої задач.

На першому етапі дослідження розв'язано задачу про вузькі бічні пластичні смуги, що виходять з вершини тріщини в один з матеріалів. Отримано вирази для довжини пластичних смуг. Здійснюючи вибір напрямку поширення смуг за умовою максимуму швидкості дисипації енергії, чисельно досліджено залежність кута їх нахилу та довжини від кута зламу межі розділу і пружних параметрів з'єднаних матеріалів. За допомогою зворотного перетворення Мелліна виведено вирази для напружень в околі кутової точки після утворення початкових пластичних смуг. Знайдено характеристичне рівняння для обчислення степеня сингулярності напружень та встановлено збереження концентрації напружень біля вершини тріщини. Отримано вираз для коефіцієнта інтенсивності напружень в кінці тріщини після появи пластичних смуг.

На другому етапі розв'язання задачі виконано розрахунок довжини вторинної зони передруйнування (зони деструкції) на продовженні тріщини та досліджено іiі залежність від конфігурації кусково- 
однорідного тіла i пружних параметрів з'єднаних матеріалів. Встановлено, що поява зони деструкції усуває концентрацію напружень у кутовій точці в широкому інтервалі параметрів з'єднання. Знайдено розкриття тріщини внаслідок утворення пластичних смуг i зони деструкції, яке може бути використано для визначення граничних навантажень.

\title{
Література:
}

1. Каминский А. А., Кипнис Л. А., Колмакова В. А. Расчет пластической зоны в конце трещины в рамках модели «трезубец». Прикладная механика. 1997. Т. 33, № 5. С. 70-76.

2. Каминский А. А., Кипнис Л. А., Дудик М. В. О начальном развитии зоны предразрушения вблизи конца трещины, выходящей на границу раздела различных сред. Прикладная механика. 2004. Т. 40, № 2. C. $74-81$.

3. Kaminsky A. A., Dudik M. V., Kipnis L. A. Initial kinking of an interface crack between two elastic media. Int. Appl. Mech. 2007. Vol. 43, No. 10. P. 1090-1099.

\section{DOI https://doi.org/10.30525/978-9934-26-043-8-16}

\section{ВПЛИВ ХВИЛЬОВИХ ПОЛІВ НА ОБ'ЄКТИ ЗАХИСТУ ТА ОСОБОВИЙ СКЛАД В УМОВАХ БОЙОВИХ ДІЙ}

\author{
Черненко А. Д. \\ кандидат військових наук, \\ начальник науково-дослідного відділу \\ наукового ицентру сухопутних військ \\ Національна академія сухопутних військ \\ імені гетьмана Петра Сагайдачного \\ м. Львів, Україна
}

Акустичні (звукові) хвилі i можливість їх використання у військових цілях віддавна були предметом розгляду військових дослідників та розробників озброєння і військової техніки. Такі хвилі, особливо інфразвукового діапазону, здатні паралізувати живу силу противника на великій території, а в окремих випадках можуть 